удк 330.342

DOI: https://doi.org/10.32851/2708-0366/2020.3.16

Шевченко О.О.

доктор економічних наук, професор, Донбаська державна машинобудівна академія ORCID: https://orcid.org/0000-0003-1825-233X

Мінаєва А.O. магістр,

Донбаська державна машинобудівна академія

Лагутін I.I. магістр,

Донбаська державна машинобудівна академія

Shevchenko Olena

Donbas State Engineering Academy

Minaieva Anastasiia

Donbas State Engineering Academy

Lahutin Ivan

Donbas State Engineering Academy

\title{
ІНСТИТУТИ СОЦІАЛЬНОГО ЗАХИСТУ НАСЕЛЕННЯ: РЕФОРМУВАННЯ ЯК ФАКТОР НІВЕЛЮВАННЯ СОЦІАЛЬНИХ АСИМЕТРІЙ
}

\author{
INSTITUTIONS OF SOCIAL PROTECTION: \\ REFORM AS A FACTOR IN LEVELING SOCIAL ASYMMETRIES
}

У статті обтрунтовано теоретичні аспекти реалізаиії державної політики соиіального забезпечення в Україні та методологічні підходи до визначення потреб $і$ базових детермінант формування, розвитку системи сочіального захисту населення в конкретно-історичних умовах як форми прояву рівня сочіалізації глобальної економіки; проаналізовано сучасний стан національної господарської системи та визначено сочіальні ризики, притаманні сучасному суспільству; запропоновано систематизувати функиіі інститутів соиіального захисту за відповідною класифікаиією та виокремити положення щуодо програми дій уряду на період подолання кризових станів в країні з урахуванням регіональних проблем соціального захисту населення, щуо дасть змогу регулювати асиметрії соиіальної незахищеності окремих категорій громадян та забезпечити рівноправність у доступі до сочуіальних послуг в умовах інклюзивності розвитку національної господарської системи.

Ключові слова: інститути соціального захисту, соиіальне забезпечення, державна політика, національна господарська система, соціальні асиметрї, інклюзивність розвитку.

В статье обоснованы теоретические аспекты реализации государственной политики социального обеспечения в Украине и методологические подходы к определению потребностей и базовых детерминант формирования, развития системы социальной защить населения в конкретно-исторических условиях как формь проявления уровня соџиализаџии глобальной экономики; проанализировано современное состояние национальной хозяйственной системы и определены сочиальные риски, присущие современному обществу; предложено систематизировать функции институтов социиальной защить по соответствующей классификации и выделить положения программь действий правительства на период преодоления кризисных состояний в стране с учетом региональных проблем социильной зашитьл населения, что позволит регулировать асимметрии социильной незащищенности отдельных категорий граждан и обеспечить равноправие в доступе к социальным услугам в условиях инклюзивности развития национальной хозяйственной системьл.

Ключевые слова: институты социальной защиты, социальное обеспечение, государственная политика, национальная хозяйственная система, социальные асимметрии, инклюзивность развития. 
The strategic goal of transformational transformations is to build a socially oriented market economy. An organic component of the latter is the system of social protection, adequate to the nature of the functioning and development of market relations. The national system of social protection of the population still remains fragmented by target, limited in available resources, characterized by low efficiency of institutions. The article substantiates the theoretical aspects of the implementation of state social security policy in Ukraine, the conceptual basis for choosing a national model of economic development of the economic system in the context of the social component of state policy (the state of the socio-economic model of national economy, the effectiveness of social policy economic system, the genesis of the modern model of the global economy) and methodological approaches to determining the needs and basic determinants of formation, development of social protection in specific historical conditions as a form of socialization of the global economy (public policy expands its format to the system of social services as an attribute of the national economic system, reflecting the level of their socialization); analyzed the current state of the national economic system (in terms of deformation of the socioeconomic subsystem, the risks of deepening social inequality) and identified social risks inherent in modern society, which allows you to choose the most effective measures to counteract the negative consequences; it is proposed to systematize the functions of social protection institutions according to the appropriate classification (such structure clearly identifies their role in regulating social reproduction on the basis of complementary combination, reducing the risks of possible decline in living standards in crisis) and to single out provisions for government action. in the country taking into account regional problems of social protection of the population that will allow to regulate asymmetries of social insecurity of separate categories of citizens and to provide equality in access to social services in the conditions of inclusive development of national economic system.

Key words: social protection institutions, social security, state policy, national economic system, social asymmetries, inclusive development.

Постановка проблеми. У сучасних умовах спостерігається тенденція до конвергенції національних систем соціального захисту населення, яка проявляється в уніфікації їхніх рис і ознак в частині забезпечення рівноваги між соціальними цілями суспільства і ринком, розвитку інститутів соціального партнерства і соціальної інклюзії, уніфікації соціальних стандартів, а також розбудови системи надання соціальних послуг. Однак зберігаються характерні для кожної моделі соціального захисту населення особливості, породжені взаємодією факторів (економічних, політичних, соціально-культурних тощо), притаманних різним господарським системам. Сучасна парадигма розвитку людства формує новітні умови та принципи економічного зростання за умов соціальної інклюзивності суспільства.

Аналіз останніх досліджень і публікацій. Теоретичні засади соціального захисту населення, його принципи, цільова мотивація та об'єктивна необхідність на ранніх етапах розвитку капіталістичної економіки були закладені у працях класиків економічної науки А. Сміта [1], Д. Рікардо [2], Д. Белла [3], А. Маршала [4], М. Лоренца [5], Т. Веблена [6], Дж. Кейнса [7] та інших. Концептуальні підходи і комплексний аналіз проблем соціалізації світової економіки та ії механізмів, диверсифікації системи соціальних послуг та іiї інструментарію, реалізації політики зростання суспільного добробуту, у тому числі на основі соціального забезпечення населення, знайшли найбільш повне відображення у працях таких науковців, як І. Колупаєва [8], О. Соскін [9], В. Бодров [10], Я. Жаліло [11], А. Гриценко [12], Н. Гражевська [13], М. Руженський [14] та інші. Стан системи соціального захисту населення України засвідчує необхідність детальнішого аналізу й надання конкретних пропозицій щодо вдосконалення наявної системи у найближчій перспективі в частині реформування інститутів соціального захисту населення як фактору нівелювання соціальних асиметрій.

Формулювання цілей статті. Водночас національна система соціального захисту населення і дотепер залишається фрагментованою за цільовим спрямуванням, обмеженою у наявних ресурсах, характеризується низькою ефективністю функціонування інститутів. Метою дослідження є систематизування функції інститутів соціального 
захисту за відповідною класифікацією, що ідентифікує їхню роль у регулюванні суспільного відтворення та пропонування концепції на період подолання кризових станів в країні з урахуванням регіональних проблем соціального захисту населення задля регулювання асиметрії соціальної незахищеності окремих категорій громадян та забезпечення рівноправності у доступі до соціальних послуг в умовах інклюзивності розвитку національної господарської системи.

Виклад основного матеріалу. В умовах глобалізації світового простору державна політика кожної країни у сфері соціального захисту населення розширює свій формат до системи надання соціальних послуг, трансформуючись у невід'ємний атрибут національних економічних систем, відбиваючи рівень їхньої соціалізації. Процеси глобалізації економічних і політичних відносин, що викликають стрімку зміну географічних кордонів, національних економічних, соціальних та культурних систем та екстраполяцію західної моделі соціально-економічного розвитку на інші традиційні моделі, неминуче породжують зміну підходів до соціального захисту населення. Одним із них $є$ наближення хоча б до стандартів забезпечення соціальних гарантій для всіх працюючих та непрацездатних і поширення їх на цих осіб незалежно від того, на території якої країни вони знаходяться.

Реалії нинішнього соціально-економічного розвитку України, породжені її поступовим втягуванням у процеси глобалізації, ставлять перед українською державою нові завдання у сфері соціального захисту населення. Зростаюча складність соціальноекономічних процесів і пов'язані з ними виклики соціальній захищеності населення України потребують розширення функцій держави в цій сфері [14]. Економічні, технологічні, демографічні, екологічні та інші фактори все сильніше впливають на розвиток української економіки та суспільства загалом, викликають потребу розроблення адекватної довгострокової стратегії і реалізації обгрунтованих програм соціального захисту населення. На думку авторів, вона має включати ефективну систему регулювання державою сфери зайнятості населення, яка $є$ ареною для прояву навичок і здібностей людини, де створюються передумови для вирішення численних проблем у всіх сферах життєдіяльності нашого суспільства.

Під час визначення основних шляхів модернізації інституту зайнятості населення слід виходити 3 того, що в основі розвитку економічної системи лежить дія об'єктивних економічних законів, що визначають логіку розвитку економічних процесів і явищ. Згідно з цим суспільна праця як джерело суспільного багатства й умова життєзабезпечення суспільства має використовуватися раціонально, у максимально доцільній формі. Останнє покладається на зайнятість населення, котра постає як функція суспільного виробництва та форма відповідності між пропозицією робочої сили і попитом на неї $[14$, с. 115]. Із цього випливає, що використання людських ресурсів належить до завжди актуальних проблем державного регулювання соціально-економічного розвитку суспільства, є стратегічною метою функціонування світової та національних економік.

Провідною ідеєю реформування інституту зайнятості в постсоціалістичних країнах $€$ відмова від патерналістської моделі його регулювання, основу якої становила концепція загальної зайнятості. На відміну від цього, ринковим соціально-економічним відносинам притаманна своя шкала індивідуальних і соціальних цінностей та відповідна цьому система соціального захисту. Внаслідок трансформаційних перетворень адміністративно-командної системи в постсоціалістичних країнах право на працю як загальний обов'язок працездатних працювати отримав форму повної свободи вибору працювати або не працювати. Зміна обов'язку суспільства гарантувати реалізацію права на працю заходами на сприяння реалізації цього права за допомогою інститутів посередництва на ринку праці, котрі виконують функцію перерозподілу робочої сили попиту і пропозиції на неї, змінила роль держави, яка була гарантом всезагальної зайнятості населення, відмовляється від цієї функції та обмежується тільки заходами 
регуляторного впливу на сферу зайнятості населення. В економічній системі України відбувається поступовий перехід від патерналістської до ринкової моделі соціального захисту населення.

На думку окремих учених, нині в Україні утворилася неадекватна соціально орієнтованій економіці модель регулярного впливу держави на цю сферу соціально-економічних відносин. Цій моделі притаманна фрагментарність, розбалансованість, наявність елементів стихійності, відмова від використання централізованих регуляторів функціонування і розвитку. Внаслідок цього заходи і дії у сфері зайнятості спрямовуються не на те, щоб цілеспрямовано впливати на процеси і явища, котрі забезпечують підтримку позитивних і унеможливлення негативних тенденцій, а на пристосування до умов, що сформувалися. Тому має місце намагання амортизувати численні наслідки, якими супроводжуються процеси системної трансформації соціально-трудових відносин, насамперед за рахунок зміни ціни праці, тривалості робочого часу, і лише незначною мірою - за рахунок змін у сфері зайнятості населення [14, с. 121].

Невирішеність означених проблем перетворило їх у головні обмежуючі чинники ефективної взаємодії інституту зайнятості із соціальним захистом населення в нашому суспільстві.

Однак у процесі ринкових перетворень в Україні держава, не створивши необхідного інституційного середовища, надала господарюючим суб'єктам право самостійного розв'язання багатьох проблем у сфері соціально-трудових відносин. Дослідження свідчать, що на результативність функціонування інституту зайнятості в нинішніх умовах істотно впливає дефіцит робочих місць - невідповідність між їх пропозицією та попитом на них [14, с. 125].

Вихідним пунктом теоретико-методологічних та прикладних розроблень, спрямованих на модернізацію інституту зайнятості населення та перехід останнього до якісно нового стану, що відповідатиме критеріям повної та продуктивної зайнятості, є сприяння створенню нових робочих місць засобами державного регуляторного впливу. При цьому слід мати на увазі, що в інституційно недосконалих економіках, до яких належить і вітчизняна, створення робочих місць має розглядатися не тільки як складник державної політики зайнятості, а й як фундаментальне політико-економічне завдання трансформаційних перетворень.

Динамічні зміни у сфері зайнятості населення нашої держави нерозривно пов'язані з їх адекватним інституційно-правовим унормуванням та приведенням у відповідність із закономірностями розвитку цього інституту. У цьому сенсі слід підкреслити, що прийняття у новій редакції Закону України «Про зайнятість населення»не ліквідувало цілої низки неузгодженостей та протиріч у нині діючому законодавстві про зайнятість населення та суміжних із ним нормативно-правових актах. В Україні, як і в більшості країн світу, має місце глибинна трансформація зайнятості населення, що проявляється у зміні ії основних форм, видів та змісту. Таким чином, нормативно правові засади функціонування і розвитку інституту зайнятості населення потребують змін і доповнень, що слід врахувати в процесі його реформування.

Трансформація інституту пенсійного забезпечення протягом останніх десятиліть виявилася болісною, малоефективною і незавершеною, не адаптованою до соціально-економічної ситуації в національній економіці. Слід підкреслити, що характерною рисою цього процесу $є$ неможливість за будь-яких умов здійснити їх миттєво. Зазвичай такі зміни охоплюють тривалість трудового життя людського покоління. До того ж, це складник реформування економічної підсистеми національного господарства.

Здійснені нині перетворення, спрямовані на подальшу трансформацію інституту пенсійного забезпечення, слід оцінювати як один з ії етапів. Тому правомірно визначити основні концептуальні засади його подальшого реформування. Стратегічною метою здійснюваних реформ у сфері пенсійного забезпечення нашої країни є ство- 
рення системи, яка би грунтувалася на засадах соціальної справедливості і забезпечила дотримання єдиного принципу під час визначення розміру пенсій для всіх громадян - тривалості трудового стажу і розмірів одержуваного заробітку. Таким чином, кардинальне розв'язання поточних і стратегічних проблем функціонування та розвитку пенсійної системи в нашій країні вбачається у поєднанні декількох напрямів iii реформування. По-перше, модернізація пенсійної системи на засадах подальшої диференціації пенсій порівняно з середнім заробітком працівника, його трудовим внеском на засадах дотримання соціальних прав для всіх громадян нашої країни шляхом упровадження відповідних стабільних інституційних механізмів щодо визначення умов пенсійних виплат. Інституціоналізацію відповідних правових засад цих заходів слід прискорити з метою повернення віри наших співгромадян у соціальну справедливість. По-друге, розширення сфери дії накопичувальної підсистеми і стимулювання розвитку недержавного пенсійного страхування. По-третє, водночас необхідні кардинальні зміни поза межами пенсійної системи у сфері зайнятості, оплати праці, детінізації економіки, іiї модернізації на інноваційних засадах і забезпечення на цій основі стабільного економічного зростання.

Невідповідність формальних і неформальних інститутів, їх неузгодженість, екстрактивний характер приводять до змін господарської системи, що неминуче викликає зменшення довіри та її кризу. Зростання суперечностей і гальмування економічного розвитку через суспільно-економічну кризу зменшують можливість перетворення формальних і неформальних інститутів, утворюючи таким чином пастку невідповідності якості економічного розвитку. Кризи як закономірний процес розвитку господарської системи мають складну природу, що проявляється як шоки соціально-економічної сфери суспільства. Протидія руйнівним процесам у системі господарювання пов'язана з аналізом криз як похідних від когнітивно-поведінкових дій, що вміщуються у фрейми господарсько-правових інститутів. Сучасний кризовий стан національної господарської системи має свої специфічні риси [15, с. 209]. Незважаючи на зростання кількості досліджень характерних рис національної моделі соціальноекономічного розвитку, не створена єдина цілісна концепція в контексті визначення вектору розвитку національної господарської системи щодо реформування інститутів соціального захисту.

Висновки. Стратегічною платформою розбудови стабільної, результативної та фінансово-спроможної вітчизняної системи соціального захисту населення є економічне зростання на базі концепції сталого розвитку з органічним поєднанням економічної, соціальної та екологічної його складових частин. Умовами і факторами забезпечення реалізації цієї концепції в Україні є реформування інституту власності, орієнтування економіки на утвердження шостого технологічного укладу, стимулювання науково-технічної діяльності в державному і корпоративному секторах, завершення розбудови національної інноваційної системи, створення сприятливого інвестиційного клімату в країні, інтеграція науки і бізнесу, нарощування всіх складників соціалізації економіки. Ключовим компонентом ефективного функціонування системи соціального захисту населення $€$ модернізація інституту зайнятості, яка передбачає такі заходи, як: створення робочих місць та посилення дієвості з боку держави податкових механізмів та кредитних важелів стимулювання роботодавців за збереження діючих і створення нових робочих місць, законодавче унормування нестандартних форм зайнятості в індивідуальному, корпоративному і державному секторах економіки, а також диверсифікацію форм зайнятості. Виокремлення положення концепції дій уряду на період подолання кризових станів в країні з урахуванням регіональних проблем соціального захисту населення дасть змогу регулювати асиметрії соціальної незахищеності окремих категорій громадян та забезпечити рівноправність у доступі до соціальних послуг в умовах інклюзивності розвитку національної господарської системи. 


\section{Список використаних джерел:}

1. A Treatise on Political Economy or the Production, Distribution, and Consumption of Wealth / J.-B. Say, 1821.

2. Ancient Rome and modern America. A comparative study of morals and manners, New York, G.P. Putnam's Sons, 1914.

3. Bell D. The Coming Post industrial Society: A Venture in social forecasting / D. Bell. New York, Basic Books, 1973.

4. Classical Keynesianism, Monetarism and the Price Level, 1961.

5. Die politische Okonomie vom Standpunkte der geschichtlichen Methode, 1853.

6. Institution, contracts and organisations : perspectives from new instution economics / ed. by Claude Menard. Cheltenham : Edgar Elgar Publishing, 2000. 460 p.

7. Keynes Monetary Theory A Different Interpretation, 1988.

8. Kolupaieva I., Shevchenko O. Justification of scenarios of state regulatory policy of Ukraine. Proceedings of the International conference of Innovation in Science and Education, March 20-22, 2019, Prague Czech Republic.

9. Соскін О.І. Народний капіталізм: економічна модель для України : монографія. Київ : Вид-во «ІСТ», 2014. 396 с.

10. Бодров В.Г. Трансформація економічних систем: концепції, моделі, механізми регулювання та управління : навч. посіб. Київ : Вид-во УАДУ, 2002. 104 с.

11. Жаліло Я. Особливості реалізації економічної політики держави в умовах сучасних тенденцій суспільного розвитку. Економічна теорія. 2016. № 1. С. 39-52.

12. Гриценко А. Реконструктивний економічний розвиток, зміст, основні напрями і вектор соціальної справедливості. Економічна теорія. 2016. № 4. С. 5-19.

13. Гражевська Н. Компаративний підхід до аналізу глобальної конкурентоспроможності національних економік. Теоретичні та прикладні питання економіки. 2014. № 1 (28). С. 15-24.

14. Руженський М.М. Соціально-економічні засади поліпшення соціального захисту економічно активного населення в контексті євроінтеграційних прагнень України. Ринок праці України: перспективи євроінтеграції : монографія за ред. І.Ф. Гнибіденко. Київ : ТОВ «ДСК центр», 2012. C. $115-130$.

15. Шевченко О.О. Еволюція господарської системи: методологія аналізу у світовій економічній думці (кінець XIX - початок XXI ст.) : монографія. Київ : «Центр учбової літератури», 2017. $304 \mathrm{c}$.

\section{References:}

1. A Treatise on Political Economy or the Production, Distribution, and Consumption of Wealth / J.-B. Say, 1821.

2. Ancient Rome and modern America.A comparative study of morals and manners, New York, G.P. Putnam's Sons, 1914.

3. Bell D. The Coming Post industrial Society: A Venture in social forecasting / D. Bell. New York: Basic Books, 1973.

4. Classical Keynesianism, Monetarism and the Price Level, 1961.

5. Die politische Okonomie vom Standpunkte der geschichtlichen Methode, 1853.

6. Institution, contracts and organisations : perspectives from new instution economics / ed. by Claude Menard. Cheltenham: Edgar Elgar Publishing, 2000. 460 p.

7. Keynes Monetary Theory A Different Interpretation, 1988.

8. Kolupaieva I., Shevchenko O. (2019) Justification of scenarios of state regulatory policy of Ukraine. Proceedings of the International conference of Innovation in Science and Education. March 20-22. Prague Czech Republic.

9. Soskin O.(2014) Narodnyj kapitalizm: ekonomichna modelj dlja Ukrajiny [Narodnyi kapitalizm: ekonomichna modely dlya Ukrainy]. Kyiv: IST Publishing House. (in Ukainian)

10. Bodrov V. (2002) Transformacija ekonomichnykh system: koncepciji, modeli, mekhanizmy reghuljuvannja ta upravlinnja [Transformation of economic systems: concepts, models, mechanisms of regulation and management]. Kyiv: Vydavnytstvo UADU. (in Ukainian)

11. Zhalilo J. (2016) Osoblyvosti realizaciji ekonomichnoji polityky derzhavy v umovakh suchasnykh tendencij suspiljnogho rozvytku [Peculiarities of realization of economic policy of the state in the conditions of modern tendencies of social development]. Economic theory, vol. 1, pp. 39-52. 
12. Hrytsenko A. (2016) Rekonstruktyvnyj ekonomichnyj rozvytok, zmist, osnovni naprjamy i vektor socialjnoji spravedlyvosti [Reconstructive economic development, content, main directions and vector of social justice]. Economic theory, vol. 4, pp. 5-19.

13. Grazhevska N. (2014) Komparatyvnyj pidkhid do analizu ghlobaljnoji konkurentospromozhnosti nacionaljnykh ekonomik [Comparative approach to the analysis of global competitiveness of national economies]. Theoretical and applied issues of economics, vol. 1 (28), pp. 15-24.

14. Ruzhens `ky`j M.M. (2012) Social’no-ekonomichni zasady` polipshennya social’nogo zaxy`stu ekonomichno akty 'vnogo naselennya $\mathrm{v}$ konteksti yevrointegracijny'x pragnen` Ukrayiny [Socio-economic principles of improvement social protection of the economically active population in the context of European integration aspirations of Ukraine]. Ry'nok praci Ukrayiny': perspekty'vy` yevrointegraciyi : Monografiya za red. I.F. Gny’bidenko. Kyiv: TOV «DSK centr», pp. 115-130.

15. Shevchenko O. (2017) Evoljucija ghospodarsjkoji systemy: metodologhija analizu u svitovij ekonomichnij dumci (kinecj KhIKh - pochatok KhKhI st.) [Evolution of economic system: methodology of analysis in world economic thought (end of XIX - beginning of XXI century)]: monograph. Kyiv: Center for Educational Literature. 